Yatsenko Alexandra Vitalievna, Odessa National Economic University

Postgraduate student, Department of Banking,

E-mail: $\underline{\text { a.v.yatsenko.biz@gmail.com }}$

\title{
FEATURES OF STRATEGY FORMATION OF BANK'S CUSTOMER RELATIONSHIP MANAGEMENT
}

\begin{abstract}
The article is concerned with the algorithm of marketing strategy choice for the bank. The author tested methods of strategy choosing, that is based on the evaluation of dynamic possibilities of the bank as compared with the market. The advantages and disadvantages of this approach are analyzed.
\end{abstract}

Keywords: bank, strategy, customer relationship marketing

An active development of relationship marketing and its directions has become one of the most significant trends in recent years $[1,2,4]$. The primary objective of the new approach is becoming the establishment long-term relationships with customers. This in its turn requires adaptation of the banks' marketing system to the new requirements of the market and consumers. There is a definition requirement of the principle of marketing strategy choice of that takes into account the possibility of the bank and the challenges that it has set itself.

In modern literature and researches, a considerable attention is paid to separate tools for attracting customers and retaining them. At the same time, in our opinion, not enough attention is paid to the selection the algorithm of marketing complex. So, Smirnov V.P., Ganzha K.A. [6] in their works considered the factors that should be viewed while the strategy formation, nonetheless the issue does not disclose how exactly should be considered these factors while a marketing strategy choosing. In the work of Monireh S. [5] the difference between the marketing strategies of different types of banks is confirmed and identified.

Is therefore an object of our work is to determine the algorithm of marketing strategy choice for commercial banks. 
With increasing competition and market saturation the number of new customers, which the company can attract, is significantly reduced. Therefore, the major source of generating income is becoming the sale of goods and the current customers services, in other words, to retain them. Thus, the concept of marketing relationships assumes the use of strategy that is aimed to loyal customers' formation. The specialists of this field point out that between the definitions the customer retention and their loyalty, there is a significant difference [3]. It is possible to retain the customers through the discounts programs and regular actions. The formation of real customer's loyalty requires a significant investment in service organization.

If the functional strategies are the elements of the overall marketing strategy, of its direction, then the business strategies cover a variety of options for interaction with the market. Therefore it is logical that the question arises, what kind of strategy the bank should implement for getting a steady state on the market and to have the opportunity to engineer the conditions for its growth. Such scholars as Karmeli A., Zott K., Chupandina E.E., Smith S.V., Popova I.M., Shaehov Y. were involved in solving the given task. At the heart of the developed approach by them, there is the comparative characteristic of organization's dynamic capabilities as compared to the development of the market (Fig. 1).

According to the algorithm, that is reflected in Fig. 1, we'll try this technique to select in the example of the bank's strategy of «Ukreximbank».

In order to assess the market dynamics we use the index of relative concentration of capital. It determines the percentage of banks, which account for $80 \%$ of the assets of the market (Table. 1). 


\section{Investigation of the banking market service parameters:}

the level of banks' concentration on the market;

the players' amount on the market

the absolute values of high-performance indicators of banks in the country

\section{Analysis of the market's dynamic indicators of country banking service (MR):}

the average growth rate of the market;

the average market growth rate of credit operations and deposits;

the average growth rate of amount of bank departments in the market.

\section{Analysis of dynamic bank indicators (BR):}

the market share occupied by the bank in dynamics;

the bank's growth rate that specialized in credit investment and deposits;

the growth rate of the bank departments' amount

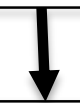

\section{Level rating of dynamic indicators of the bank (BR).}

\begin{tabular}{|l||l|}
\hline \multicolumn{1}{|c|}{ BR $>$ MR } & \multicolumn{1}{c|}{ BR $<$ MR } \\
\hline $\begin{array}{l}\text { The level of dynamic capabilities of the } \\
\text { bank is high, the bank can quickly adapt } \\
\text { to the changes in the environment and has } \\
\text { a sustainable competitive advantages. }\end{array}$ & $\begin{array}{l}\text { The level of dynamic capabilities of the } \\
\text { bank is low, the bank not quickly enough } \\
\text { adapt to market conditions and losing } \\
\text { competitive position. }\end{array}$ \\
\hline
\end{tabular}

Fig . 1 Analysis's algorithm of dynamic capabilities of bank.

Table 1

Level analysis of market concentration of bank service in Ukraine for the period

2008-2015. (as of 01.01)

\begin{tabular}{|l|l|c|c|c|c|c|c|c|c|}
\hline № & Indicators & 2008 & 2009 & 2010 & 2011 & 2012 & 2013 & 2014 & 2015 \\
\hline 1 & Bank amount & 175 & 184 & 182 & 176 & 176 & 176 & 180 & 163 \\
\hline 2 & $\begin{array}{l}\text { Earning assets, } \\
\text { bln. UAH }\end{array}$ & 599,4 & 926,1 & 880,3 & 942,1 & 1054,3 & 1127,2 & 1278,1 & 1316,9 \\
\hline 3 & $\begin{array}{l}\text { Banks amount, } \\
\text { which own 80\% } \\
\text { of assets }\end{array}$ & 32 & 36 & 29 & 31 & 33 & 34 & 32 & 23 \\
\hline 4 & $\begin{array}{l}\text { Coefficient of } \\
\text { relative } \\
\text { concentration,\% }\end{array}$ & 18,3 & 19,6 & 15,9 & 17,6 & 18,8 & 19,3 & 17,8 & 14,1 \\
\hline
\end{tabular}

In Table 1, the decline of the relative concentration is well-marked in the post-crisis period (2009-2010 and 2014-2015). The interesting feature of the Ukrainian banking market is increasing of bank amount in period of 2008-2010 
which is not typical for the world market. Low-quality interbank management and banking supervision by NBU, the artificial distortion of data reporting has led to an increase in amount of unstable banks in the period 2014-2015. Despite this, the asset size of the banking system at the beginning of 2015 rose to 1316.9 billion. $\mathrm{UAH}$, for this purpose it should be noted also the presence of high inflation. It can be argued that there is a significant reallocation of funds from small banks to large, so $80 \%$ of banking system assets was distributed among 23 of the 163 institutions. Thus, as of end the period under consideration the banking system of Ukraine is characterized by a decrease in the number of players, increasing the level of concentration and therefore a decrease in competition.

The most well known indicator is Herfindahl-Hirschman's Index, assesses the concentration level and monopolization of the market. Thus, the capital concentration is not a competition equivalent, the existence of barriers to entry and exit in the market leads to a high concentration of capital in a few institutions, and vice versa. This indicator is a key in the Anti-trust Law in USA, which aims to prevent the monopolization of the market. [7].Therefore, we consider it appropriate to analyze the concentration state of banking capital on this indicator in the dynamics, in Ukraine.

Coefficient of Herfindahl-Hirschman shows what place and share is occupied by the institutions, whose share is negligible.

$$
H H I=\sum_{i=1}^{n} S_{i}{ }^{2}
$$

Figure 2 shows the dynamics of the Herfindahl-Hirschman index for assets and in the context of the customers' type (individuals and legal entities) and the product (deposits and credits). 


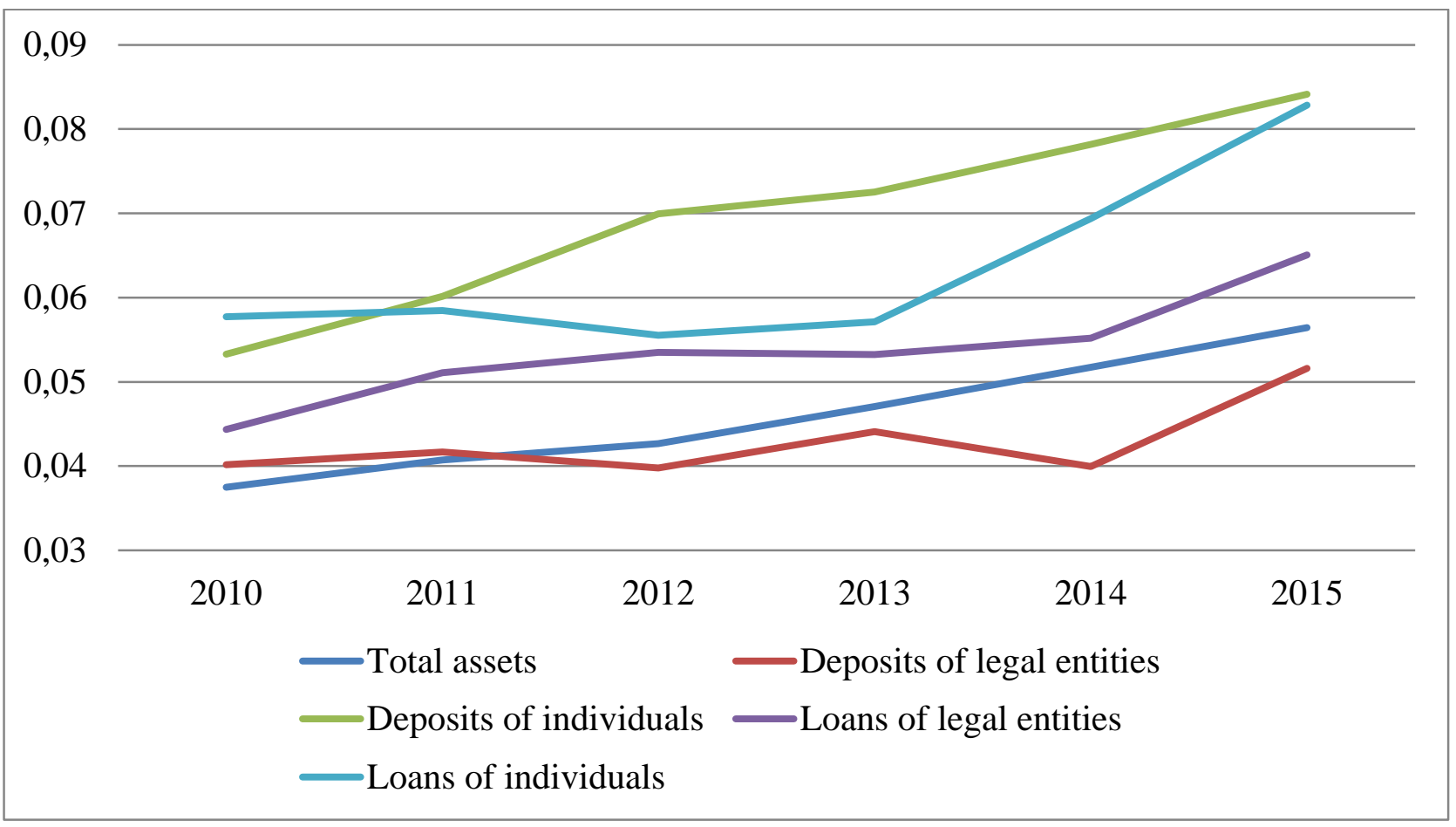

Fig.2. Dynamics of Herfindahl-Hirschman's indices for the period 2010-2015 (bln. UAH)

Figure 2 indicates the stable growth of the capital concentration in the banking market. The highest concentration is observed for the funds of individuals. However the market of banking services in Ukraine still refers to the low concentration, which once again confirms the conclusions of the high level of competition in this market.

Level evaluation of the dynamic capabilities of bank's involves comparison of indicators in dynamics of the bank's market data. Table 2 presents the analysis of growth indicators of the market and the bank «Ukreximbank» for the period 2009-2015.

Data of Table. 2 indicate that for the five-year the period an average annual growth rate of assets, deposits and credit investments exceeded 100\%. This should take into account that indicators could rise due to the increase exchange rates and inflation. Average annual growth in assets and deposits of «Ukreximbank» higher than those of the market, which indicates the presence of competitive advantages and the right strategy. But credit investments grow with the lower rate as compared to the market, which may be due to a moderate policy of the bank crediting individuals and legal entities, or the presence of more profitable credit products in the market. 
Table 2

Level evaluation of market concentration of banking service in Ukraine for period 2010-2015

\begin{tabular}{|l|l|c|c|c|c|c|c|c|}
\hline № & Indicators & 2010 & 2011 & 2012 & 2013 & 2014 & 2015 & Tp \\
\hline 1 & $\begin{array}{l}\text { Assets of market, bln. } \\
\text { UAH }\end{array}$ & 880,3 & 942,1 & 1054,3 & 1127,2 & 1278,1 & 1316,9 & 1,084 \\
\hline 2 & $\begin{array}{l}\text { Loans of market, bln. } \\
\text { UAH }\end{array}$ & 723,1 & 746,4 & 808,2 & 694,4 & 799,2 & 873,6 & 1,039 \\
\hline 3 & $\begin{array}{l}\text { Deposits of market, bln. } \\
\text { UAH }\end{array}$ & 472,8 & 598,1 & 712,2 & 791,0 & 922,7 & 989,4 & 1,159 \\
\hline 4 & Amount of bank stores & 16339 & 15898 & 16220 & 15808 & 15436 & 13359 & 0,961 \\
\hline 5 & $\begin{array}{l}\text { Assets of } \\
\text { «Ukreximbank», bln. }\end{array}$ & 57,2 & 73,2 & 75,1 & 87,9 & 94,3 & 126,0 & 1,171 \\
\hline 6 & $\begin{array}{l}\text { LAH } \\
\text { «Ukreximbank», bln. }\end{array}$ & 48,3 & 52,1 & 52,7 & 40,4 & 42,3 & 52,1 & 1,015 \\
\hline 7 & $\begin{array}{l}\text { UAH op } \\
\text { «Ukreximbank», bln. }\end{array}$ & 26,7 & 38,4 & 42,5 & 67,0 & 61,0 & 90,9 & 1,278 \\
\hline 8 & $\begin{array}{l}\text { Bank stores of } \\
\text { «Ukreximbank» }\end{array}$ & 122 & 122 & 126 & 125 & 123 & 120 & 0,997 \\
\hline
\end{tabular}

In Figure 3 it is reflected the asset's dynamics of the market and the bank «Ukreximbank» for the period 2011-2015.

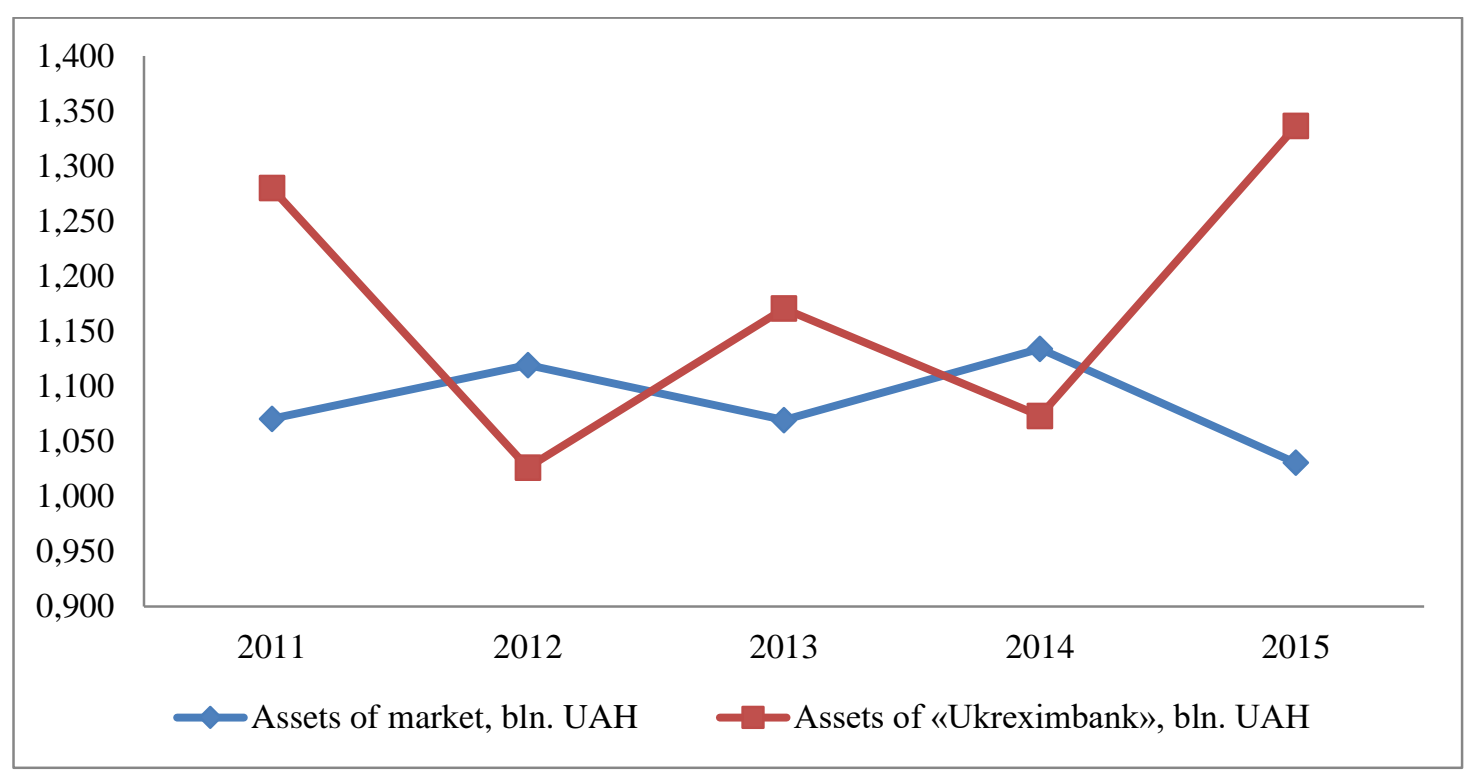

Fig. 3. The growth rate dynamics of the banking market's assets and the bank «Ukreximbank» for the period 2011-2015 
As is seen in Figure 3, the dynamics of growth of assets «Ukreximbank» opposite dynamics of the market. During the period 2014-2015,. the growth rate of its assets was significantly $133.6 \%$, while the market grew by only $3 \%$. Table. 3 shows a summary of the results of the analysis of the level of dynamic capabilities «Ukreximbank».

Table 3

Level analysis of dynamic capabilities of «Ukreximbank»

\begin{tabular}{|l|c|c|c|}
\hline \multicolumn{1}{|c|}{ Indicators } & $\begin{array}{c}\text { Dynamic of market } \\
(\mathrm{BR}>\mathrm{MR})\end{array}$ & $\begin{array}{c}\text { Dynamic of bank } \\
(\mathrm{BR})\end{array}$ & Dynamic capabilities \\
\hline Assets & 1,084 & 1,171 & MR $<$ BR \\
\hline Loans & 1,039 & 1,015 & MR $>$ BR \\
\hline Deposits & 1,159 & 1,278 & MR $<$ BR \\
\hline Bank stores & 0,961 & 0,997 & MR $<$ BR \\
\hline
\end{tabular}

Tables 2 and 3 show that the bank «Ukreximbank» has the strengths that allows it maintain a steady growth of indicators. Figure 4 is a graphical representation of dynamic capabilities of the bank compared to the market and recommended strategy.

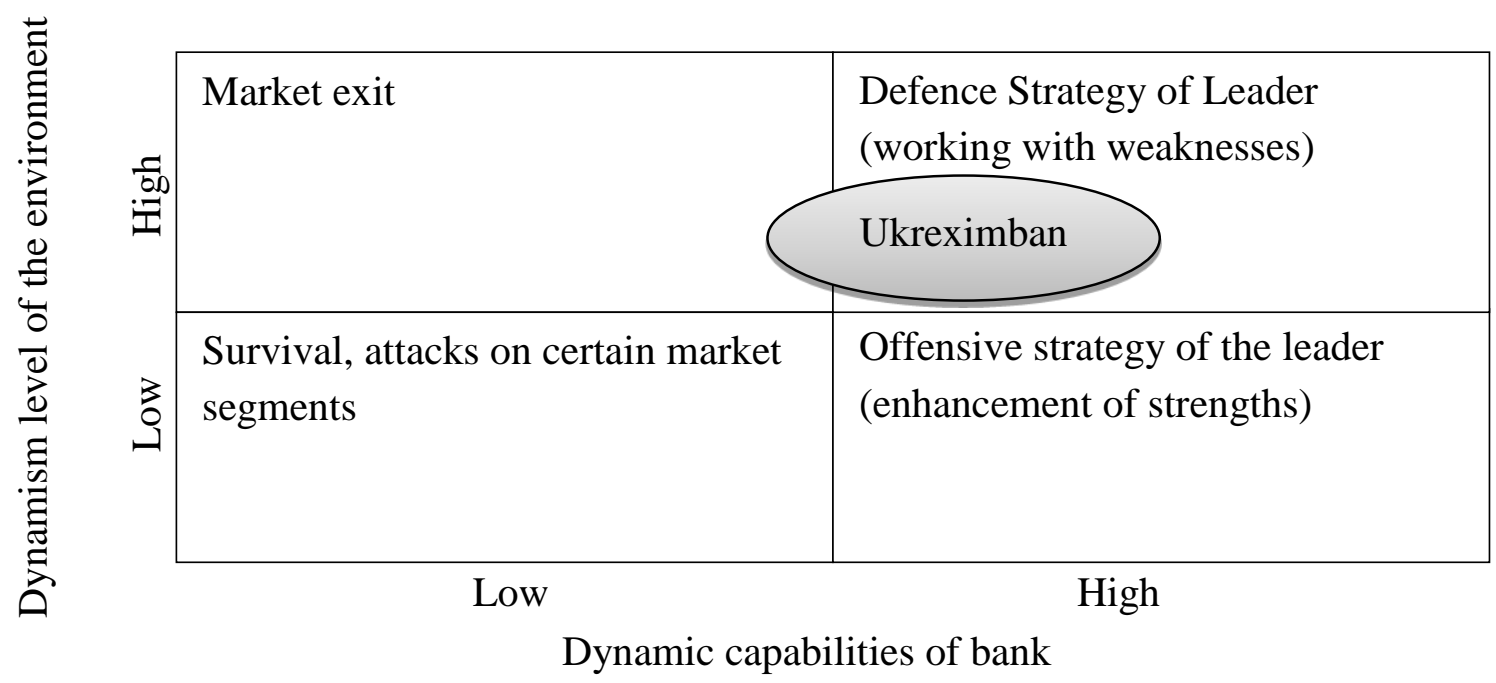

Fig. 4. Choice of strategy based on the estimates of the parameters of complexity and dynamism of the environment and the dynamic capabilities of banks

As is reflected in Figure 4, the bank is recommended to take a defensive strategy - to work with its weaknesses. The banks that have already taken a strong position in their markets, can stick basically defensive strategies that enable them to retain positions gained. The volume and type of action needed for retaining 
situation will vary depending on degree of tension and nature of competition, which the bank will face. If a bank has a dominant position in the market, it may have a superior of cost through economies of scale, or to their experience, which can be used as a basis for protection by selectively reducing the cost of products. Alternatively, is possible to create obstacles to penetration, provide, where possible, protection of its knowledge and retention of key specialists.

Given technique have several advantages: ease of analysis, the availability of source data, the comparative characteristic of the market, evaluation of market position. The disadvantage is the possibility of contact with the bank in zone, where one of two strategies can be chosen, which can have opposing recommendations technique does not account for the internal ability of banks and quality characteristics. From our point of view, such an approach should be used as the basic method and positions' assessment of the market. For selecting a narrower strategy it is necessary to include the internal factors into the technique that evaluate the possibility of the bank development.

\section{References:}

1. Gronroos, C. (1994), From marketing mix to relationship marketing: Towards a paradigm shift in marketing, Marketing Decisions, Vol. 32 (2), p. 4-32.

2. Gummesson, E. (1987), The new marketing - developing long-term interactive relationships, Long Range Planning, Vol. 20 (4), p. 10-20.

3. Hooley, G.J., Saunders, J.A., Piercy, N.F (2005), Marketing strategy and competitive positioning - Harlow, Pearson Education Limited, 800 p.

4. Payne, A. (1995), Advances in Relationship Marketing - London, Kogan Page, $354 \mathrm{p}$.

5. Monireh, S. (2015), Differences in marketing strategies of various types of banks, Journal of Economic Regulation, Vol. 1(6), p.120-128.

6. Smirnov, V.P., Ganzha, K.A. (2014), Strategic planning in a commercial bank. [Electronic resource] - Access mode: http://ekonomika.snauka.ru/2014/05/5235

7. Ivanchenko O.V., Semernikova Y.A. (2015), The concept of relationship marketing in the activities of small businesses, Concept, Vol. S24, p. 1-7. 